\title{
Morphology and molecular identification of Eurytrema spp. worm in Aceh cattle, Indonesia
}

\author{
MUHAMMAD HANAFIAH ${ }^{1, \boldsymbol{v}}$, TEUKU ZAHRIAL HELMI ${ }^{2}$, AMALIA SUTRIANA ${ }^{3}$, MUHAMMAD BAHI ${ }^{4}$ \\ ${ }^{1}$ Laboratory of Parasitology, Faculty of Veterinary Medicine, Universitas Syiah Kuala. Jl. Tgk. Hasan Krueng Kalee No. 4, Banda Aceh 23111, Aceh, \\ Indonesia. Tel./fax. : +62-651-7551536, `email: hanafi_2015@unsyiah.ac.id \\ ${ }^{2}$ Laboratory of Biochemistry, Faculty of Veterinary Medicine, Universitas Syiah Kuala. Jl. Tgk. Hasan Krueng Kalee No. 4, Banda Aceh 23111, Aceh, \\ Indonesia \\ ${ }^{3}$ Laboratory of Pharmacology, Faculty of Veterinary Medicine, Universitas Syiah Kuala. Jl. Tgk. Hasan Krueng Kalee No. 4, Banda Aceh 23111, Aceh, \\ Indonesia \\ ${ }^{4}$ Department of Chemistry, Faculty of Mathematics and Natural Sciences, Universitas Syiah Kuala. Jl. Syech Abdurrauf No. 3, Banda Aceh 23111, Aceh,
} Indonesia

Manuscript received: 4 October 2021. Revision accepted: 29 November 2021.

\begin{abstract}
Hanafiah M, Helmi TZ, Sutriana A, Bahi M. 2021. Morphology and molecular identification of Eurytrema spp. worm in Aceh cattle, Indonesia. Biodiversitas 22: 5654-5661. The objective of this research was to determine the species of Eurytrema spp. in Aceh cattle which were slaughtered in slaughterhouses located in Banda Aceh, Indonesia. Identification of Eurytrema spp worm species was performed by Semichon's Carmine staining, SEM and molecular method. The result from Semichon's Carmine staining and SEM method showed that worms coded E2 and E3 were Eurytrema cladorchis indicated by clearly visible protruding cirrus while worms coded E1, E4 and E5 were E. pancreaticum indicated by the absence of protruding cirrus. Molecular characterization of Eurytrema spp. produced fragments of approximately $700 \mathrm{bp}$ in length. The phylogenic tree showed that Eurytrema spp. from Aceh cattle consisted of 2 clades: clade 1 was E. pancreaticum, while clade 2 was E. cladorchis. DNA sequencing result showed that the similarity of worm samples coded 1, 4, and 5 were 98.90\% similar to E. pancreaticum (KJ767631.1 and KC535543.1), and 96. 33\% similar to E. cladorchis (MN566134.5 and MN566140.1), whereas the worm samples coded 2 and 3 were $97.53 \%$ similar to E. pancreaticum (KY490000.1 until KY490004.1), and 97.55\% similar to E. cladorchis (MN566135.1 until MN566140.1). This research was able to identify E. pancreaticum and E. cladorchis in Aceh cattle slaughtered in Banda Aceh slaughter houses.
\end{abstract}

Keywords: Cattle, Eurytrema pancreaticum, Eurytrema cladorchis, identification, molecular

\section{INTRODUCTION}

The Aceh cattle breed came from a cross between local cattle (assumed to be a descendant of Bos sondaicus) and zebu cattle from India (Bos indicus) which occurred hundreds of year ago (Sutarno and Setyawan 2016). At present time, Aceh cattle population has reached an alarmingly low number, so Aceh cattle feedstock needs to be improved by increasing birth rate and lowering death rate percentage (Widyaningrum et al. 2021). The cause of this diminishing number is due to the low growth rate of Aceh cattle, which is much slower than the rate of crossbred cattle (Agus et al. 2018). Other than the slow growth, according to Schwertz et al. (2015) parasitic disease caused by digenetic trematode Eurytrema worm, which is a pancreas parasite with low pathogenicity, could be related to the decrease of livestock productive performance and may end in death.

One species of parasitic worm that infect the pancreas and biliary tract of cattle is Eurytrema spp. The genus Eurytrema appears to be confined to parts of South East Asia, East Asia and Latin America (Mohanta et al. 2015), where annual mortality caused by this pancreatic fluke ranges between 1-3\% (Ilha et al. 2005; Okajima et al. 2016). Eurytrema pancreaticum infection can be debilitating towards animal health and can cause clinical and subclinical diseases, as well as causing great economic losses and medical costs and lowering overall productivity (Schwertz et al. 2015), it may be associated with mortality and loss of productive performance in animals due to chronic pancreatitis ( $\mathrm{Su}$ et al. 2018). The parasites have also been known to impair calf growth, cause progressive weight loss, lower feed conversion, malnutrition, and impair milk production. Eurytrematosis case in cow has been reported in Brazil (Rachid et al. 2011; Quevedo et al. 2013) where clinical and pathological features observed shows chronic and progressive wasting related to interstitial pancreatitis. The prevalence of parasitism in Brazil varied between regions. Lucca et al. (2015) reported in the western region of Santa Catarina State, the prevalence of Eurytrema was as high as $69 \%$.

$\mathrm{Xu}$ et al. (2015) has researched the expression profile of global MicroRNAs (miRNAs) from adult E. pancreaticum utilizing next gen sequencing technology combined with real-time quantitative PCR. Mohanta et al. (2015) was to identify Eurytrema flukes both by morphology and molecular properties on the basis of 18-subunit ribosomal RNA (18S rRNA) gene as well as internal transcribed spacer 2 (ITS2) to clarify their phylogenetic status. Figueira et al. (2014) also identified unique morphological characteristics and molecular features in E. coelomaticum worms found in cattles in South Brazil. Mohanta et al. 
(2015) confirmed the presence of E. cladorchis in the biliary tract of cattle (Bos indicus) in Bandarban a mountainous district in Bangladesh. Research on the differences of trematode worm parasites Eurytrema spp. until now had not been reported for Aceh cattle. Considering the lack of information on species and the morphology of Eurytrema spp., this research may aid in better understanding eurytrematiasis in an effort to find efficient strategies to prevent and control infestations of the parasite in cattle from Aceh. In order to better manage cattle in Aceh, more accurate identification of species and morphology of the worms is required.

The purpose of this research is to determine the difference in species of Eurytrema spp. worms obtained from Aceh cattle slaughtered in Banda Aceh slaughterhouses by using Semichon's Carmine staining, scanning electron microscopy (SEM) and molecular method.

\section{MATERIALS AND METHODS}

\section{Study location and period}

A total of 40 pancreas samples were collected from Aceh cattle from Banda Aceh, Indonesia slaughterhouses. The Aceh cattle that were slaughtered were mostly from Aceh Besar district, and partly from Pidie and Aceh Jaya districts. The samples were collected into plastics and labeled. The separation and identification of Eurytrema spp. worms were performed in the Laboratory of Parasitology, Faculty of Veterinary Medicine, Universitas Syiah Kuala, Banda Aceh. Eurtyrema spp. worms were put inside petri dishes, cleaned and later stained using Semichon's Carmine staining. SEM analysis were performed in the Center of Biology Research, LIPI Cibidong, Zoology Division, SEM Laboratory, Cibinong, Indonesia. For DNA extraction, 5 Eurytrema spp. were taken from the pancreas. The worms were rinsed in distilled water, fixed in absolute ethanol solution, and then stored at $4^{\circ} \mathrm{C}$. DNA extraction, electrophoresis and amplification of Eurytrema spp. worms was performed at Inter University Centre (PAU) Gadjah Mada University. This research was carried out between December 2020 and March 2021.

Semichon's Carmine Staining Method Eurytrema spp. was stained using Semichon's Carmine method which referred to Cable (1961). Eurytrema worm specimens were put into semichon's carmine staining solution barely covering the specimen thoroughly. The staining solution was previously diluted to an equal volume of $70 \%$ alcohol and stored for 1 to a few hours. The over stain color was removed by washing the specimen with $70 \%$ alcohol twice. Subsequently, the specimen was dipped in $0.5 \%$ to $1 \%$ HCL and $70 \%$ alcohol until the specimen is pink in color. Then, the specimen was washed twice or three times using $70 \%$ alcohol to remove acid and prevent further staining process. Subsequently, dehydration was carried out by dipping the specimens in $80 \%$ and $95 \%$ alcohol for 1 hour, each solution. Then, the specimen was dipped in another new $95 \%$ alcohol or in absolute alcohol if methyl salicylate was used to clean up the specimen. The next step was cleaning the specimen using neutral creosote, terpinol or methyl salicylate. The specimen was briefly washed in xylol then, attached to a glass object and added entellan, covered with a glass deck carefully to ensure the entellan is distributed thoroughly. The slide was stored for 24 hours to let the entellan dry before observing under a microscope using 40x magnification.

\section{Scanning electron microscope (SEM) method to observe worm micro structure}

Eurytrema spp. observations by SEM were performed to explore the small morphological features of Eurytrema spp. Specimen preparation was performed in the Center of Biology Research, LIPI Cibinong, Biology Division, SEM Laboratory, Cibinong, according to a particular protocol. Samples were processed at $4^{\circ} \mathrm{C}$ in several stages: (i) Cleaning, the sample was soaked in cacodylate buffer (42.6 gr of $0.2 \mathrm{M}$ sodium caccodylate $+1000 \mathrm{~mL}$ aquadest with a pH of 8.4) for approximately 2 hours, then agitated in an ultrasonic cleaner for 5 minute; (ii) Presification, the sample was put into a $2.5 \%$ glutaraldehyde solution $(5 \mathrm{~mL}$ glutaraldehyde+caccodylate buffer up to $40 \mathrm{~mL}$ ) for several hours to 2 days; (iii) Fixation, the sample was soaked in $2 \%$ tannic acid ( $2 \mathrm{~g}$ of tannic acid in $100 \mathrm{~mL}$ of caccodylate buffer) for 6 hours to several days, then washed with caccodylate buffer for 5 minutes for 4 times; (iv) Dehydration, the sample was soaked 5 minutes in $50 \%$ alcohol for 4 times, then immersed in $70 \%$ alcohol, $85 \%$ alcohol, and $95 \%$ alcohol for 20 minutes each (at room temperature), then with absolute alcohol for 10 minutes 2 times; (v) Drying, the sample was submerged for 10 minutes in tert butanol 2 times, then freezed until frozen and transferred to freeze drier/vacuum drier until dry; (vi) Installation, the specimen was fixed on the specimen stub according to the needs and stages; (vii) Coating, the specimen was coated with $\mathrm{Au}$ (Aurum) using the ION COATER tool. The microscope used was the JSM-IT200 InTouchScope ${ }^{\mathrm{TM}}$ Scanning Electron Microscope. Pictures were taken to observe morphological differences between the available worms using the appropriate magnification (Goldstein et al. 1992).

\section{Eurytrema spp. observation using PCR}

The DNA extraction results were amplified using PCR in the 5.8S and IT2 regions. Polymerase chain reaction (PCR) was performed using a $50 \mu \mathrm{L}$ mixture that contained $10 \mu \mathrm{L}$ sample DNA. Reverse primer was JB9 neu (5'-GCT GCA TTC ACA AAC AAC CCG-3') and forward primer was 3SC (5'-CGG TGG ATC ACT CGG CTC G-3') (Mirza and Kurniasih 2002). The PCR mixture contained $0,2 \mathrm{mM}$ of each primer, $100 \mathrm{mM}$ dNTP (Fermentas), 60 $\mathrm{mM}$ Tris- $\mathrm{HCl}$ (pH 9.0), $15 \mathrm{mM}$ (NH4) 2SO, $2 \mathrm{mM}$ $\mathrm{MgCl}$, and $1 \mathrm{U}$ Biotaq (Bioline, MA, USA) for each reaction. Amplification was performed using PTC-150 Minicycler thermocycler (MJ Research Inc, MA, USA) with an initial denaturation of 7 minutes on $94^{\circ} \mathrm{C}$, followed by 35 cycles for 1 minute in $95^{\circ} \mathrm{C}, 1$ minute in $60^{\circ} \mathrm{C}, 1$ minute in $72^{\circ} \mathrm{C}$ and final incubation for 10 minutes in $72^{\circ} \mathrm{C}$. The amplification product was then electrophorized in $1,1 \%$ 
agarose gel etydium bromide with 100 bp marker (Biolabs, MA, USA) and a positive control containing Eurytrema spp. DNA. A negative control that did not contain DNA material was also used.

\section{Sequencing}

PCR product was sequenced by $\mathrm{ABI}$ PrismBigDye Terminator Cycle Sequencing Kit (Applied Biosystems, Foster City, CA, USA).

\section{Data analysis}

The data was presented in picture and table format and then the accumulated data were analyzed descriptively. Phylogenetic tree and sequence alignments based on the 5.8S and ITS2 gene of the Eurytrema spp. were then created by using MEGA version 6 software. Constructed by the neighbor-joining method, based on 1.000 bootstrapped data sets; distance value was calculated by using the Kimura 2 parameter model. Fasciola hepatica was used as the out group to provide stability to the generated tree. The sequence identity was generated by using the software Bioedit (Tamura et al. 2013).

\section{RESULTS AND DISCUSSION}

Observation on 40 pancreases (Figure 1) from Aceh cattle slaughtered in Banda Aceh slaughterhouses appeared to be infested by trematode Eurytrema spp. worms. Eurytrema are considered low pathogenic parasites (Ilha et al. 2005; Schwertz et al. 2016), yet are very frequently found at necropsy or at slaughterhouses in Aceh and other parts of West Indonesia.

The results of the examination on pancreas samples of Aceh cattle showed the presence of worms from the trematode class of the genus Eurytrema spp. (Figure 1). However, the species of these worms could not be determined due to the morphology of the worms can not be observed specifically. In general, the morphology of Eurytrema spp. was reddish in color and slightly oval in shape. This worm has a blunt and rounded anterior end, and has a short tongue-like shape at the posterior end. The body is thick and armed with spines, which often disappear as they mature. This worm has an oral sucker and a ventral sucker, pharynx, osophagus, testes and genital pore, and cirrus sac. The ovaries are near the midline, behind the testes, and the uterus is at the back of the body. The vitelline glands are follicular and located laterally. The species of Eurytrema worms found in the pancreas was still unknown and thus staining was required.

\section{Morphology observation by worm staining}

The results obtained in this research by Semichon's Carmine staining method showed that the worms found in the pancreas (Figure 1) of Aceh cattle were $E$. pancreaticum (Figure 2, E1, E4 and E5) and E. cladorchis (Figure 2, E2 and E3). E. pancreaticum worms found in this research morphologically were $8-16 \mathrm{~mm}$ in length and $5-8 \mathrm{~mm}$ in width. The body was flat and tapered. Oral sucker was located at the anterior region of the body while ventral sucker was located around the middle region of the body. Visible reproductive organs were a pair of testicles lobes located opposite of one another above ovarium lobulated with worm eggs situated inside the uterus. Ovarium with lobulated is an identifying characteristic of E. pancreaticum (Kumar et al. 2018), uterus, and glandula vitelline. Cirrus sac was located in the middle between oral and ventral sucker, cirrus was present but protruding (Figure 2, E1, Inset).

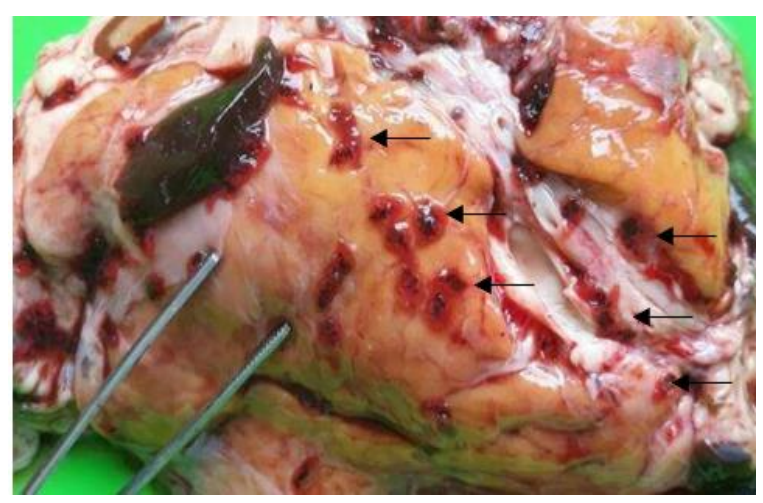

Figure 1. Eurytema spp. worms (arrows) in the pancreas of Aceh cattle

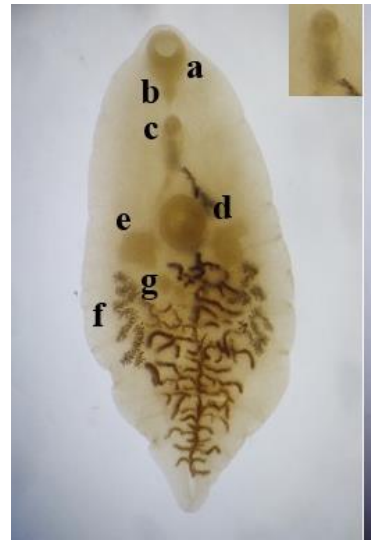

E1

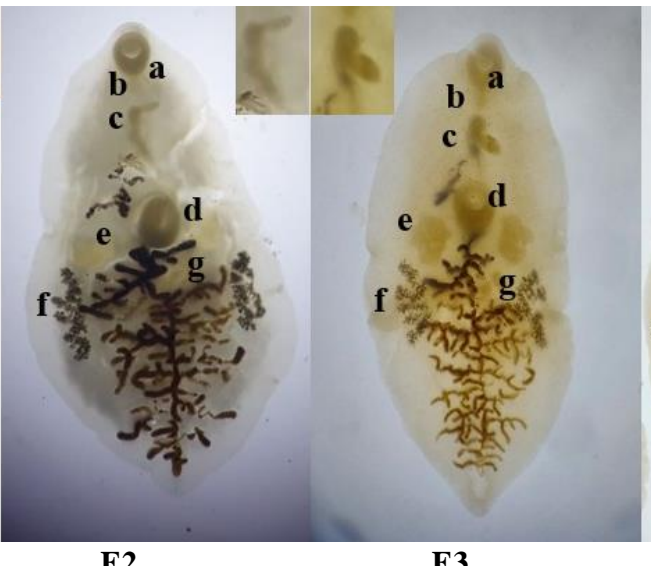

E2
E3

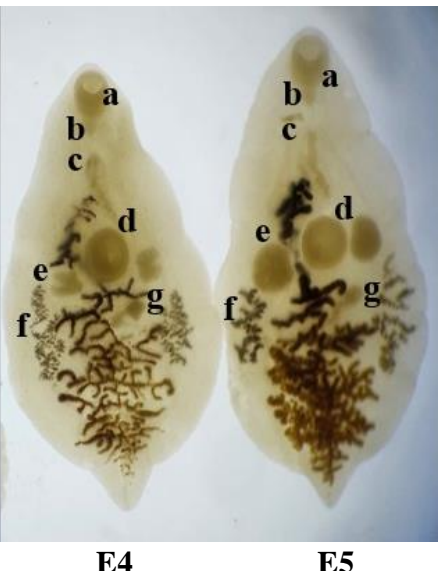

E4
E5

Figure 2. The morphology of genus Eurytrema worms. E1, E4 and E5: E. pancreaticum, E2 and E3: E. cladorchis. a: oral sucker, b: pharynx, c: cirrus; d: ventral sucker; e: testes; f: vitelline follicles and g: ovarium. Scale bar: $94.5 \mu \mathrm{m}$ 
According to Mohanta et al. (2015), species identification of Eurytrema spp. worm has always been room for controversy especially related to the obtained morphologies, making interpretation differs between researchers. In the last several years, significant advancement in microscopic technology has led to new discoveries on the morphology and anatomy of parasitic worms (Faulwetter et al. 2013; Lopes-Torres et al. 2015; Gonçalves et al. 2016; Conn et al. 2018).

According Chai et al. (2013) morphologically E. pancreaticum worms have larger oral sucker compared to their ventral sucker, testes with lobes, ovarium with or without lobulated, and grouped vitellaria follicle with clear separation. Eurytrema cladorchis worms obtained in this research had morphological features such as protruding digitiform cirrus (Figure 2; E2 and E3. Inset), elongated cirrus sac, branching testicles which were located symmetrically at the posterolateral region towards the acetabulum. Ventral sucker (acetabulum) was larger (on average $322.67 \mu \mathrm{m}$ ) compared to the oval shaped oral sucker (on average $279.07 \mu \mathrm{m}$ ) similiar morphology was also observed previously in research (Figueira et al. 2014 Mohanta et al. 2015) which classifies the worms as the $E$. cladorchis species.

In China, there are at least seven species, including $E$. cladorchis, E. coelomaticum, E. fukienensis, E. hydropotes, E. minutum, E. pancreaticum and E. sphaeriorchis; however, E. pancreaticum is considered as predominant species in ruminants ( $\mathrm{Li}$ et al. 2013). The study of Okajima et al. (2016) explained that eurytrematosis was endemic in Japan particularly in Kagoshima, Okinawa, and Shimane regions. In another study showed that E. pancreaticum eggs appeared in fecal samples of five camels in Karamoja sub region of North-eastern Uganda (Nakayima et al. 2017).
Eurytrema cladorchis was discovered living in the pancreatic tract of domestic ruminants. Afterward, the flukes were reported from both wild deer (Muntiacus muntjak, Hydropotes inermis) and domestic ruminants in the mountainous area of Fujian, Zhejiang, Jiangxi and Anhui Provinces, China (Cai et al. 2012). Morphological identification of E. cladorchis in Nepal has been performed by Mohanta et al. (2015). In this research we compared the morphometry features and morphology of Eurytrema worms from Bangladesh with obtained E. cladorchis. The result of this study which identifies Eurytrema cladorchis in cattle in Indonesia especially in Aceh cattle is the first to be conducted as far as our knowledge. It is the goal of the researchers that this research will add new information on the characteristic of Eurytrema worms especially $E$. cladorchis.

The prevalence of E. pancreaticum was detected in Aceh cattle with a prevalence rate of $0.4 \%$ (Hanafiah et al. 2019). Lucca et al. (2015) mentions that the prevalence of E. pancreaticum in cattle may occur, in extreme cases up to $100 \%$, while (Okajima et al. 2016) reported that the prevalence of eurytrematiasis was less than $1 \%$ in animal slaughterhouses in Japan.

\section{Scanning electron microscope (SEM)}

SEM observation on obtained Eurytrema spp. displayed micro non-protruding cirrus on Eurytrema pancreaticum (EP), while clearly protruding cirrus is visible on Eurytrema cladorchis worms (EC) (Figure 3).

This result is supported by research conducted by Chai et al. (2013) which stated that morphologically, $E$. pancreaticum did not have a protruding cirrus (Figure 3. a), while E. cladorchis has a protruding cirrus (Figure 3. b). clearly protruding cirrus is visible on E. cladorchis worms (EC) (Figure 3) Mohanta et al. (2015).

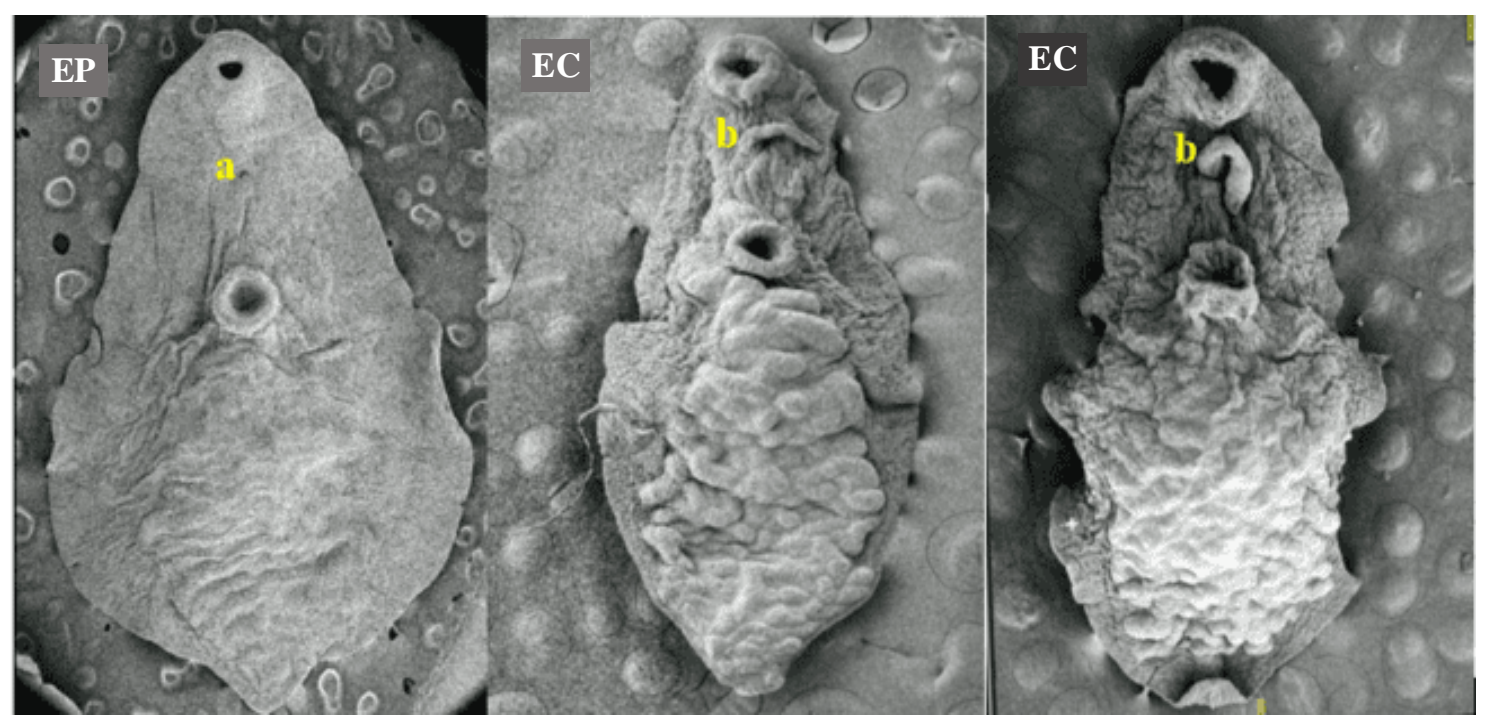

Figure 3. The morphology of genus Eurytrema spp. worm. EP: Eurytrema pancreaticum, EC: Eurytrema cladorchis, a: Cirrus does not protrude, b: Cirrus visibly protrudes. Scale bar: $500 \mu \mathrm{m}$ 


\section{Repetitive $\mathbf{R 5 2 9}$ sequence amplification}

Amplification results of DNA from blood, pancreas, and Eurytrema spp. samples were obtained by using forward primer 3SC and reverse primer JB9 neu with different master mix, in which mix PCR Go Tag specifically attached to sample DNA copy of D1, E1, E2 as well as $\mathrm{J} 1$ dan $\mathrm{J} 2$ producing $700 \mathrm{bp}$ in length, while D2 did not show any band. Using master mix PCR Bio Line, E1, E2 and J1 samples produced $700 \mathrm{bp}$ in length, while D1, D2 the band is amplified in an unspecified region with 5.8 $\mathrm{S}$ and IT2 primers (Figure 4). Meanwhile, worm samples E1, E2, E3, E4 and E5 produced 700 bp in length (Figure 5).

The result of amplification of Polymerase chain reaction (PCR) on 5.8S and ITS2 site in this research showed that the DNA length of the Eurytrema spp. found was the same with research conducted by Mirza and Kurniasih (2002) which was 700 bp in samples from Makassar, Yogyakarta, and Aceh, while using ITS2, 15 samples of Eurytrema spp. worms on agarose gel $1 \%$ which produced $1500 \mathrm{bp}$. Different results were also obtained in research by Mohanta et al. (2015) who used 8S rRNA on Eurytrema spp. worms which showed 1784 bp DNA, while the ITS2 was 229 bp in length.

The results of nucleotide BLAST (Basic Alignment Search Tool) which are shown in NCBI showed the homology between Eurytrema spp. worms in this research (sequenced product) with the sequence of several worms in GenBank. For worm samples E1, E4, and E5 they were $98.90 \%$ homologous with E. pancreaticum, and $96.33 \%$ homologous with E. cladorchis. Worm samples E2 and E3 were $97.53 \%$ homologous with E. pancreaticum, and 97. $55 \%$ homologous with E. cladorchis.

Estimated evolution differences with the E. cladorchis genotype from Bangladesh according to research by Cai et al. (2012) stated that the difference is low in values between 0,000 (identical) up to 0,002 (similarities 99.8\%) for $18 \mathrm{~S}$ rRNA and for ITS2 was 0,000 . In $18 \mathrm{~S}$ region rRNA, the estimated divergent evolution between $E$. cladorchis from Bangladesh and E. pancreaticum (DQ401034) from China showed similarity of 99.4-99.6\%, while using ITS2 E. cladorchis and E. pancreaticum from Bangladesh has a similarity $96.2 \%$. Genetic identity of $E$. cladorchis from Bangladesh with E. cladorchis and E. fukienensis from China respectively were 98.1-98.3 and 98.4-98.6\% respectively.

Table 1 showed the genetic distance of Eurytrema pancreaticum Aceh isolate obtained from Aceh cattle (isolate number 4101133_1, 4101139_4, 4101141_5) with other Eurytrema pancreaticum isolates. Eurytrema pancreaticum Aceh isolate had genetic distance of 0.018 and 0.055 when compared to Eurytrema_pancreaticum isolate 5.8S_ribosomal_RNA_gene (KJ767631.1) and Eurytrema_cladorchis_isolate_LS09_5.8S_ribosomal_RN A_gene (MN566140.1), respectively. Whereas E. cladorchis Aceh isolate (isolate number 4101135_2 dan 4101137_3) had genetic distance of 0.032 as compared to isolate of Eurytrema_pancreaticum_5.8S ribosomal_RNA gene (KJ767631.1) and Eurytrema_cladorchis_isolate
LS09 5.8S_ribosomal_RNA_gene (MN566140.1), and had 0.023 genetic distance compared with E. pancreaticum Aceh isolate (isolate number 4101133_1, 4101139_4, 4101141_5).

\section{Phylogenetic analysis result}

Sequence results obtained were later used to construct a phylogenetic tree which was then compared to determine the difference level between isolates. Eurytrema spp. sequences from Aceh cattle slaughtered in Banda Aceh slaughterhouses were then compared to sequence data from 10 different strain/isolates from the GenBank. The sequence organizing and phylogenetic tree were performed by MEGA X.0 software (Figure 6).

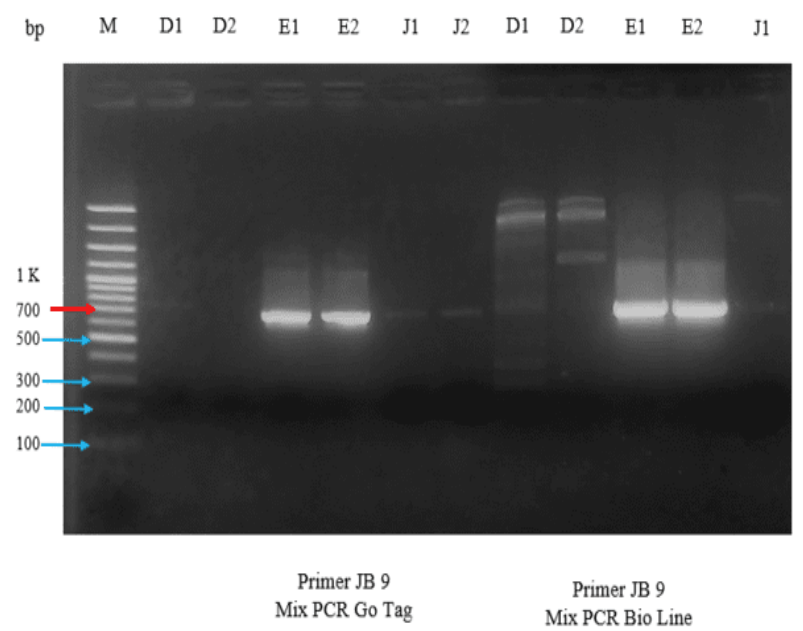

Figure 4. Sample DNA amplification result on agarose gel $1 \%$. M: marker, D1 and D2: Aceh cattle blood, E1 and E2: Eurytrema spp. worm, J1 and J2: Aceh cattle pancreas

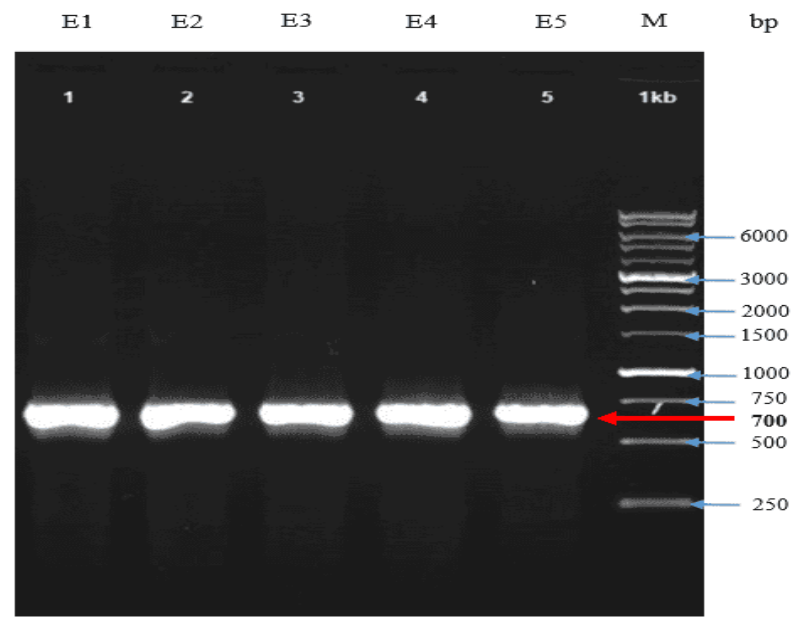

Figure 5. Sample DNA amplification on gel agarose 1\%. M: marker, E1, E2, E3, E4 and E5: Eurytrema spp. worms 
Table 1. Data of genetic distance between Eurytrema isolate from Aceh with data from GenBank

\begin{tabular}{|c|c|c|c|c|c|c|c|c|c|c|c|c|c|c|c|}
\hline $\begin{array}{c}\text { Code/number of } \\
\text { isolate }\end{array}$ & 1 & 2 & 3 & 4 & 5 & 6 & 7 & 8 & 9 & 10 & 11 & 12 & 13 & 14 & 15 \\
\hline $\begin{array}{ll}1 . & \mathrm{KJ} 767631.1\end{array}$ & & & & & & & & & & & & & & & \\
\hline 4101133_1 & 0,018 & & & & & & & & & & & & & & \\
\hline 4101139_4 & 0,018 & 0,000 & & & & & & & & & & & & & \\
\hline 4101141_5 & 0,018 & 0,000 & 0,000 & & & & & & & & & & & & \\
\hline 4101135_2 & 0,032 & 0,023 & 0,023 & 0,023 & & & & & & & & & & & \\
\hline 4101137_3 & 0,032 & 0,023 & 0,023 & 0,023 & 0,000 & & & & & & & & & & \\
\hline MN566140.1 & 0,055 & 0,046 & 0,046 & 0,046 & 0,032 & 0,032 & & & & & & & & & \\
\hline LC006031.1 & 0,051 & 0,041 & 0,041 & 0,041 & 0,027 & 0,027 & 0.004 & & & & & & & & \\
\hline EF547132.1 & 0,240 & 0,246 & 0,246 & 0,246 & 0,240 & 0,240 & 0,247 & 0,246 & & & & & & & \\
\hline KF734795.1 & 0,221 & 0,234 & 0,234 & 0,234 & 0,227 & 0,227 & 0,234 & 0,234 & 0,023 & & & & & & \\
\hline KU563717.1 & 0,221 & 0,227 & 0,227 & 0,227 & 0,221 & 0,221 & 0,215 & 0,215 & 0,080 & 0,075 & & & & & \\
\hline DO379986.2 & 0,234 & 0,240 & 0,240 & 0,240 & 0,227 & 0,227 & 0,234 & 0,234 & 0,027 & 0,023 & 0,070 & & & & \\
\hline MN831475.1 & 0,234 & 0,240 & 0,240 & 0,240 & 0,227 & 0,227 & 0,234 & 0,234 & 0,027 & 0,023 & 0,070 & 0,000 & & & \\
\hline KC535543.1 & 0,000 & 0,018 & 0,018 & 0,018 & 0,032 & 0,032 & 0,055 & 0,051 & 0,240 & 0,221 & 0,221 & 0,234 & 0,234 & & \\
\hline MW620063.1 & 0,523 & 0,522 & 0,522 & 0,522 & 0,522 & 0,522 & 0,552 & 0,551 & 0,515 & 0,549 & 0,563 & 0,517 & 0,517 & 0,523 & \\
\hline
\end{tabular}

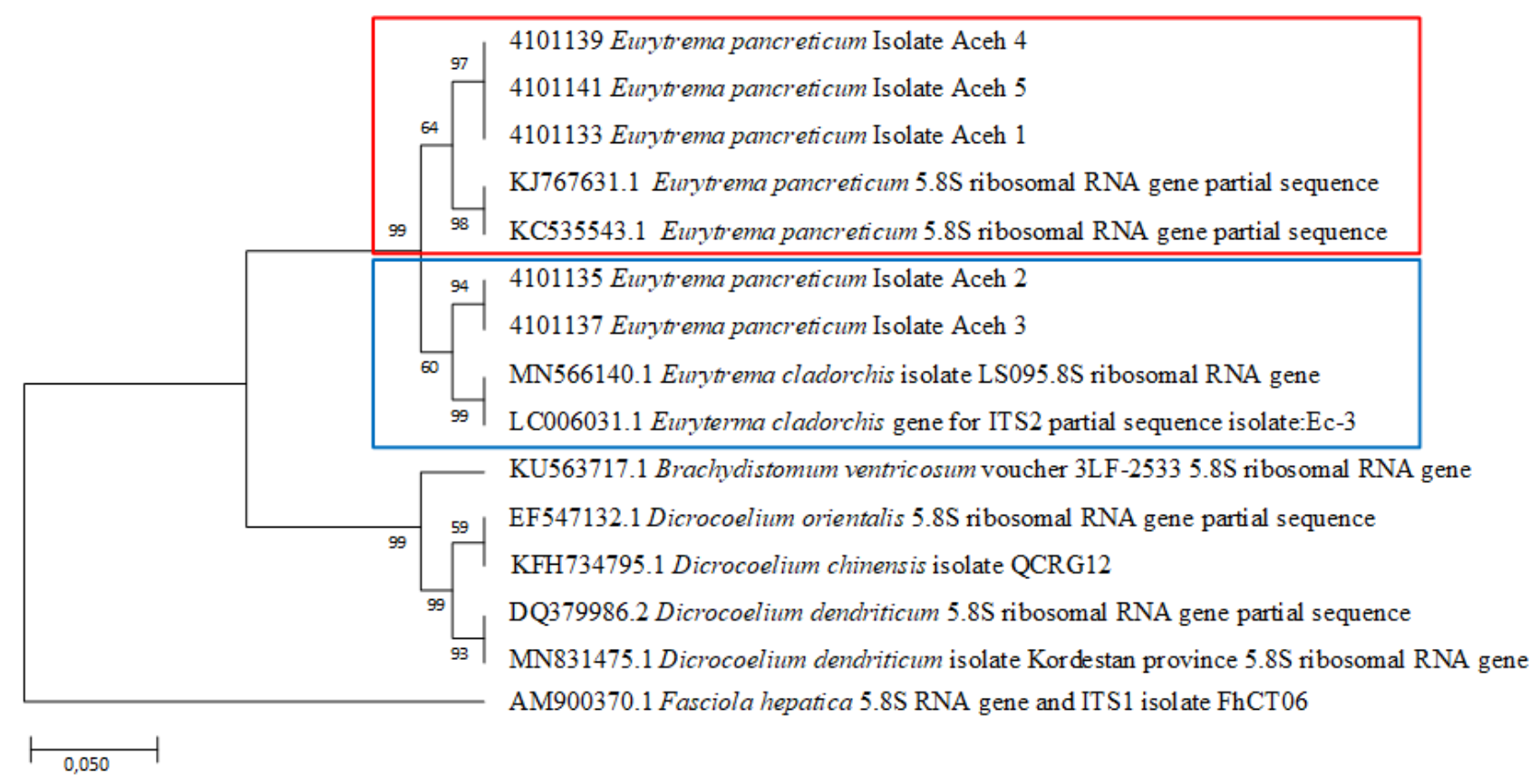

Figure 6. Neighbour Joining by $5,8 \mathrm{~S}$ and ITS2 (700 bp) sequence of E. pancreaticum and E. cladorchis from Indonesia and other sequences related to Dicrocoelidae family. Fasciola hepatica was used as outgroup. Bootstrap value higher than 50\% is shown in tree

The phylogenetic tree construction result (Figure 6) showed that Eurytrema spp. from Aceh consisted of 2 clades, where clade 1 consists of 2 sub clades in which each consisted of E.pancreaticum from Aceh cattle in Indonesia and E. pancreaticum (KJ767631.1), E. pancreaticum (KC535543.1) from Bangladesh while clade 2 consisted of 2 sub clades as well which consisted of E.cladorchis form Aceh Indonesia, E. cladorchis (LC006031.1) isolate from Bangladesh and E. cladorchis (MN566140.1) from Liangshan, China.

Cai et al. (2012) stated that phylogenetic analysis of $E$. cladorchis 18S and ITS2 genotypes from Bangladesh formed a monophyletic clade in phylogram. Phylogram constructed from $18 \mathrm{~S}$ rRNA has 2 clades, where clade 1 consists of E. coelomaticum, E. cladorchis and E. fukienensis from China while clade 2 consists of $E$. cladorchis from Bangladesh whereas D. dendriticum is different from genus Eurytrema. In phylogram obtained from ITS2 sequences, E. pancreaticum is a relative from clade E. cladorchis while genus Dicrocoelium members form a different clade.

Clades formed by E. cladorchis from Bangladesh is vastly different from E. cladorchis and E. fukienensis reported by Cai et al. (2012) in China. The estimated evolutionary divergent value showed that the genetic distance between E. cladorchis from Bangladesh and $E$. cladorchis reported from China was 1.7-1.9\%. This showed that E. cladorchis in Bangladesh and in China are genetically quite different. E. pancreaticum Aceh isolates from this research when compared to E. pancreaticum from 
Bangladesh, India, has an evolutionary divergence value of $1.8 \%$, while the E. cladorchis Aceh isolate and E. cladorchis from Liangshan, China, showed the genetic distance of $3.2 \%$. This result showed that E. pancreatium from Aceh cattle when compared with those from Bangladesh are genetically quite different, while the $E$. cladorchis from Aceh cattle when compared with China and Bangladesh are genetically vastly different.

In conclusion, this research was able to identify $E$. pancreaticum and E. cladorchis in Aceh cattle obtained from Banda Aceh slaughterhouses. E. cladorchis indicated by clearly visible protruding cirrus while worms $E$. pancreaticum indicated by the absence of protruding cirrus. The DNA amplification of Eurytrema spp. worm was 700 bp in length. The phylogenetic tree showed that Eurytrema spp. from Aceh cattle formed 2 clades, clade 1 consisted of Eurytrema pancreaticum, while clade 2 consisted of Eurytrema cladorchis.

\section{ACKNOWLEDGEMENTS}

The author would like to express their gratitude to Arsiah from PAU Gadjah Mada University, Yogyakarta, for her assistance during the DNA isolation process of Eurytrema spp. and the molecular examination, as well as with the DNA sequence delivery. This study was supported by the Ministry of Research Technology and Higher Education of the Republic of Indonesia (No.10/UN11.2 / PT.01.03 / PNBP/ 2021). The authors acknowledge the facilities, scientific and technical support from Zoology Characterization Laboratories, Indonesian Institute of Sciences through E-Layanan Sains, Lembaga Ilmu Pengetahuan Indonesia.

\section{REFERENCES}

Agus A, Widi TSM. 2018. Current situation and prospect of beef cattle production in Indonesia - A review. Asian-Australas J Anim Sci 31 (1): 1-8. DOI: $10.5713 /$ ajas.18.0233.

Cable DM. 1961. An Illustrated Laboratory Manual of Parasitology. Burges Publishing Company, Minniapolis.

Cai Z, Zhang Y, Ye X. 2012. Phylogenetic relationships of the genus Eurytrema from domestic and wild animal based on 18S rRNA sequences. Parasitol Res 111 (4): 1637-1644. DOI: 10.1007/s00436012-3002-y.

Chai JY, Bahk YY, Sohn WM. 2013. trematodes recovered in the small intestine of stray cats in the Republic of Korea. Korean J Parasitol 51 (1): 99-106. DOI: 10.3347/kjp.2013.51.1.99.

Conn DB, Świderski Z, Miquel J. 2018. Ultrastructure of digenean trematode eggs (Platyhelminthes: Neoophora): A review emphasizing new comparative data on four European Microphalloidea. Acta Parasitologica 63: 1-14. DOI: 10.1515/ap-2018-0001.

Faulwetter S, Vasileiadou A, Kouratoras M, Thanos D, Arvanitidis C. 2013. Micro-computed tomography: Introducing new dimensions to taxonomy. Zookeys 263: 1-45. DOI: 10.3897/zookeys.263-4261.

Figueira GF, de Oliveira VHS, Taroda A, Alfieri AA, Headley SA. 2014. Molecular characterization of Eurytrema coelomaticum in cattle from Paraná, Brazil. Braz J Vet Parasitol 23 (3): 383-386. DOI: 10.1590/S1984-29612014022.

Goldstein JI, Newbury DE, Echlin P, Joy DC, Romig JR AD, Lyman CE, Fiori C, Lifshin E. 1992. Scanning Electron Microscope and X-ray Microanalysis: A Text for Biologist, Materials Scientist, and Cytologist $2^{\text {nd }}$ Edition. Plemun Press, New York.
Gonçalves JP, Oliveira-Menezes A, Maldonado Jr A, Carvalho TMU, de Souza W. 2016. Ultrastructural and cytochemical characterization of T1 and T2 secretory bodies from the tegument of Echinostoma paraensei. Micron 80: 59-65. DOI: 10.1016/j.micron.2015.09.008.

Hanafiah M, Aliza D, Abrar M, Karmil F, Rachmady D. 2019. Detection of parasitic helminths in cattle from Banda Aceh, Indonesia. Vet World 12 (8): 1175-1179. DOI: 10.14202/vetworld.2019.1175-1179.

Ilha MRS, Loretti AP, Reis ACF. 2005. Wasting and mortality in beef cattle parasitized by Eurytrema coelomaticum in The State of Parana, Southern Brazil. Vet Parasitol 133 (1): 49-60. DOI: 10.1016/J.VETPAR.2005.02.013.

Kumar S, Stecher G, Li M, Knyaz C, Tamura K. 2018. MEGA X: Molecular evolutionary genetics analysis across computing platforms. Mol Biol Evol 35 (6): 1547-1549. DOI: 10.1093/molbev/msy096.

Li H, He SW, Li WY, Li F. 2013. Prevalence of parasites in goats in xiangxi autonomous prefecture of Hunan province, China. Heilongjiang. Anim Sci Vet Med 20: 97-98.

Lopes-Torres EJ, Maldonado Jr A, Anjos DH, de Souza W, Miranda K. 2015. Redescription of Spirura guianensis (Nematoda: Spiruridae) from a rare South American Gracile Opossum. Acta Tropica 150: 8793. DOI: 10.1016/j.actatropica.2015.07.003.

Lucca N, Stedille F, Schwertz C, Henker L, Gabriel M, Mendes R, Pappen F, Rosa L. 2015. Principais parasitoses gastrointestinais em bovinos provenientes de propriedades leiteiras de municípios do Alto Uruguai, Santa Catarina. Extensão Tecnológica: Revista de Extensão do Instituto Federal Catarinense 3: 63-68.

Mirza I, Kurniasih. 2002. Identification of Eurytrema sp. in cattle based on morphological characteristics. Seminar Nasional Teknologi dan Veteriner 327-333.

Mohanta UK, Ichikawa-Seki M, Hayashi K and Itagaki T. 2015. Morphological and molecular characterization of Eurytrema cladorchis parasitizing cattle (Bos indicus) in Bangladesh. Parasitol Res 114 (6): 2099-2105. DOI: 10.1007/s00436-015-4398-y.

Nakayima J, Kabasa W, Aleper D, Okidi D. 2017. Prevalence of endoparasites in donkeys and camels in Karamoja sub-region, Northeastern Uganda. J Vet Med Anim Health 9 (1): 11-15. DOI: 10.5897/JVMAH2016.0499.

Okajima J, Shibata K, Takahashi E, Nagafuchi T, Okajima K, Nonaka N. 2016. Current status and its epidemiological consideration of Fasciola and Eurytrema infections in beef cattle of Japan. J Vet Med Sci 78 (5): 785-790. DOI: 10.1292/jvms.15-0469.

Quevedo PS, Mendes M, Pappen FG, Soares MP, Muller G, Farias NAR. 2013. Pancreatite intersticial crônica em bovino causada por Eurytrema coelomaticum. Ciência Rural 8: 1449-1452.

Rachid M, Neto HMA, Facury-Filho EJ, Carvalho AU, Valle GR, Vasconcelos AC. 2011. Chronic interstitial pancreatitis and chronic wasting disease caused by Eurytrema coelomaticum in Nelore cow. Arq Bras Med Vet Zoo 63: 741-743. DOI: 10.1590/S010209352011000300028

Schwertz CI, Lucca N J, da Silva AS, Baska P, Bonetto G, Gabriel ME, Centofanti F, Mendes RE. 2015. Eurytrematosis: An emerging and neglected disease in South Brazil. World J Exp Med 5 (3): 160-163. DOI: $10.5493 /$ wjem.v5.i3.160.

Schwertz CI, Gabriel ME, Henker LC, Bottari NB, do Carmo G, Guarda NDS, Moresco RN, Machado G, Morsch V, Schetinger MRC, Stedille FA. 2016. Oxidative stress associated with pathological changes in the pancreas of cattle naturally infected by Eurytrema coelomaticum. Vet Parasit 223: 102-110. DOI: 10.1016/j.vetpar.2016.04.034.

Su X, Zhang Y, Zheng X, Wang XX, Li Y, Li Q, Wang CR. 2018. Characterization of the complete nuclear ribosomal DNA sequences of Eurytrema pancreaticum. J Helminthol 92 (4): 484-490. DOI: 10.1017/S0022149X17000554.

Sutarno, Setyawan AD. 2016 Review: The diversity of local cattle in Indonesia and the efforts to develop superior indigenous cattle breeds. Biodiversitas 17 (1): 275-295. DOI: 10.13057/biodiv/d170139.

Tamura K, Stecher G, Peterson D, Filipski A, Kumar S. 2013. MEGA 6: Molecular evolutionary genetics analysis version 6.0. Molecular Biology and Evolution 30: 2725-2729. DOI: 10.1093/molbev/mst197.

Widyaningrum R, Budisatria I G S, Mukhtar, Maharani D. 2021. Profile and population dynamics of Aceh cattle in livestock breeding and forage centre. The 3rd International Conference of Animal Science and Technology IOP Conf Series: Earth Environ Sci 788: 012003. DOI: $10.1088 / 1755-1315 / 788 / 1 / 012003$. 
Quevedo PS, Mendes M, Pappen FG, Soares MP, Muller G, Farias NAR. 2013. Pancreatite intersticial crônica em bovino causada por Eurytrema coelomaticum. Ciência Rural 43 (8): 1449-1452. DOI: 10.1590/S0103-84782013005000104.
Xu M-J, Wang C-R, Huang S-Y, Fu J-H, Zhou D-H, Chang Q-C, Zhu XQ. 2013. Identification and characterization of microRNAs in the pancreatic fluke Eurytrema pancreaticum. Parasites Vectors 6 (1): 16. DOI:10.1186/1756-3305-6-25. 